\title{
Gandrung Dance Performance as a Media for Hindu Religious Education at Pura Dalem Majapahit
}

\author{
Ni Nyoman Dian Tri Utami \& I Ketut Sudarsana* \\ Universitas Hindu Negeri I Gusti Bagus Sugriwa Denpasar, Indonesia
}

\begin{abstract}
Education for human life is an absolute need to be fulfilled and plays a very important role in the preservation of cultural heritage. Art is a cultural heritage. In Pemecutan Kelod Village, Denpasar City, there is a sacred art, namely the Gandrung dance which is staged during the piodalan series at the Dalem Majapahit Temple. Only boys can dance. The problems discussed are 1) How is the Gandrung Dance Performance Procession as a Media for Hindu Religious Education at Pura Dalem Majapahit Br. Munang Maning Pemecutan Kelod Village, Denpasar City? 2) What are the factors behind the Gandrung Dance Performance as a Hindu Religious Education Media at Pura Dalem Majapahit, Br. Munang Maning Pemecutan Kelod Village, Denpasar City? 3) What educational values are contained in the Gandrung dance performance as a Hindu Religious Education Media at Pura Dalem Majapahit Br. Munang Maning Pemecutan Kelod Village, Denpasar City?. This research is classified as qualitative research. Data were obtained by using data collection methods, observations, interviews, literature studies and documentation. The data that has been collected is then analyzed using descriptive methods at the stages of reduction, data presentation, and drawing conclusions. The results of this study indicate: 1) Gandrung dance performances at Pura Dalem Majapahit, namely: patching gelungan gandrung, wearing make-up, pawintenan, ngaturang bhakti, wearing gelungan, mecaru, mesolah and pemuput. 2) The factors behind the performance of the Gandrung dance can be seen from the function of adaptation, goal achievement, integration, and latency. 3) Hindu religious education values contained in the Gandrung Dance Performance: (a) skill values, (b) ethical values, (c) aesthetic values, (d) cultural preservation values, (e) love values.
\end{abstract}

Keywords: Hindu religious education media, Gandrung dance, educational values.

\section{Introduction}

Perkembangan pendidikan di Indonesia ialah salah satu sektor yang sangat penting didalam pembangunan nasional. Untuk meningkatkan pembangunan tersebut maka kualitas hidup manusia di Indonesia perlu adanya tuntunan dalam mutu pendidikan. Tanpa adanya pendidikan maka kelompok manusia tidak dapat hidup berkembang ke arah maju, sejahtera dan bahagia untuk konsep pandangan hidup (Ihsan, 2011: 22). Pendidikan memiliki peran dalam menjaga suatu warisan budaya dimasyarakat. Kebudayaan adalah hasil dari ciptaan manusia yang didapat melalui suatu hasil proses belajar, setelah kebudayaan tersebut tercipta maka manusialah yang akan melestarikannya (Ihromi, 2006: 18). Pendidikan terbagi menjadi 3 jenis jalur pendidikan, yaitu pendidikan formal,informal, dan nonformal (Beni, 2012: 5$6)$.

Pendidikan formal ialah suatu kegiatan yang bertahap secara sistematis yang dimulai dari suatu kegiatan dari sekolah dasar hingga keperguruan tinggi atau sederajat. Pendidikan nonformal mencakup semua kegiatan organisasi dan sistematik di luar sistem sekolah. Pendidikan informal merupakan proses yang akan berlangsungsepanjang usia manusia sehingga manusia didunia ini memperoleh sikap, keterampilan, nilai, dan pengetahuan yang bersumber dari pengalaman hidupnya sehari-hari, pengaruh dari lingkungan meliputi dampak hubungan dengan keluarga, hubungan dengan tetangga serta hubungan dengan masyarakat dan melalui media. Pendidikan nonformal merupakan bagian terpenting pada suatu kegiatan yang lebih besar dan dilakukan secara mandiri atau sadar bagi siswa tertentu untuk mencapai tujuan belajarnya.

\footnotetext{
* Corresponding author.

E-mail address: iketutsudarsana@uhnsugriwa.ac.id (I Ketut Sudarsana)
} 
Jalur pendidikan yang dipergunakan dari tari Gandrung yang dipentaskan di Pura Dalem Majapahit yakni jalur informal, karena penari dapat meningkatkan kemampuan dan keterampilan dalam beradaptasi dengan masyarakat sebagai penonton serta dalam proses pementasan, penari mengembangkan kepribadian dan rasa percaya diri dalam menarikan tarian Gandrung, serta masyarakat bekerja sama dengan meluangkan waktu dari kesibukan masingmasing tapi masih memiliki kesadaran untuk bergotong royong dalam mempersiapkan pelaksanaan pementasan tarian Gandrung.

Manusia tidak akan bisa lepas dari kebudayaan, karena baik buruknya perkembangan seorang sangat ditentukan oleh faktor budaya. Secara garis besar menurut (Koentjaraningrat, 2004: 2) unsur-unsur dari kebudayaan dapat di golongkan menjadi 7 yakni : (1) Sistem religi, (2) Sistem organisasi kemasyarakat, (3) Sistem pengetahuan, (4) Sistem bahasa, (5) Sistem kesenian, (6) Sistem mata pencaharian, (7) Sistem teknologi \& peralatan . Hal yang mendasari unsur kebudayaan yakni sistem religi. Sistem religi atau agama adalah bagian terpenting dalam suatu kebudayaan. Semua aktivitas keagamaan yang dilakukan oleh manusia didasarkan pada getaran jiwa yang bisa disebut dengan emosi keagamaan. Pada sistem religi dalam suatu kebudayaan memiliki ciri-ciri untuk sedapat mungkin mampu memelihara emosi keagamaan antara pengikut- pengikutnya. Serta kesenian adalah salah satu warisan kekayaan budaya yang di dukung oleh suatu kelompok masyarakat tertentu untuk dapat menunjukkan ciri-ciri serta budaya suatu daerah. Kesenian yang terdapat pada Pulau Bali saling memiliki keterkaitan yang sangat erat, terutama dalam tradisi, adat, budaya agama Hindu di Bali yang selalu menyertai dalam setiap pelaksanan ritual khususnya keagamaaan.

Seni dan budaya adalah perpaduan estetika budaya yang di dasari atas ajaran Agama Hindu. Masyarakat Hindu di Bali menggunakan seni sebagai perantara dalam melaksanakan prosesi yadnya. Yudhabahkti \& Watra (2007: 34) menyatakan pada pementasan seni tari dapat dibedakan menjadi 2, yakni tari profan dan tari sakral. Tari profan merupakan suatu tarian yang tidak ada bersangkutan dengan agama / tujuan keagamaan, kemudian pada tari sakral mengacu pada sesuatu tarian yang disucikan dalam upacara yandya dan disesuaikan dengan keperluan. Tari sakral ialah suatu tarian yang pada saat pementasanya bersifat religius dan umumnya bertemakan Ketuhanan didalamnya (Rianta, 2020).

Pada salah satu Pura yang terdapat di Kota Denpasar yang masih mempertahankan seni keagamaannya yang tergolong dalam seni sakral yaitu tari Gandrung yang dipentaskan di Pura Dalem Majapahit, Br. Munang-Maning, Desa Pemecutan Kelod, Kota Denpasar. Dianggap sakral karena dijawibkan untuk tampil disuatu upacara yadnya dan dibatasi oleh dasa kala patra yaitu suatu ketentuan mengenai tempatnya yang terpilih , waktu yang terpilih , dan penarinya yang terpilih (Narawati, 2013). Tari Gandrung merupakan tarian yang dianggap sakral karena merupakan tarian yang hanya di tarikan pada piodalan Pura Dalem Majapahit di purnama sasih kenam. Keunikan yang terdapat dari tari Gandrung di Pura Dalem Majapahit, Br. Munang-Maning, Desa Pemecutan Kelod, Kota Denpasar yakni penari yang akan menarikan tari Gandrung di tarikan oleh penari laki- laki, karena taksu dari tari Gandrung tersebut ada pada gelungan penari laki-lakinya yang kemudian dimandatkan kepada generasi berikutnya untuk dapat diwarisi. Tari Gandrung tidak bisa ditarikan oleh sembarangan orang, pada pemilihan penari yang dipilih adalah anak laki-laki yang berumur 7-10 tahun karena dianggap masih belia dan secara mutlak dengan cara niskala karena penari Gandrung memiliki taksu dari Bhatara Sesuunan Due Gandrung, penari bermimpi menari tari Gandrung di Pura Dalem Majapahit dengan gerakan yang luwes tanpa mengalami kesulitan dan dipilih oleh Jero Mangku Pura Dalem Majapahit.

Tari Gandrung bagi masyarakat Br. Munang Maning memiliki nilai-nilai religi yang sangat penting sehingga kehadirannya pada setiap nyineb setelah piodalan di Pura Dalem Majapahit dianggap sebagai simbol untuk menjauhkan bala atau unsur kebatilan. Pada saat piodalan di Pura Dalem Majapahit, Br. Munang-Maning, Desa Pemecutan Kelod, Kota Denpasar terdapat kepercayaan masyarakat agar tetap mementaskan tari Gandrung sebagai tarian sakral yang dipercayai sebagai penetralisir dari kekuatan jahat baik secara nyata (sekala) dan tidak nyata (niskala) dan ini termasuk dalam nilai religi. Berdasarkan fenomena dan keunikan yang terdapat dalam pementasan tari Gandrung membuat peneliti tertarik untuk melaksanakan penelitian dan berfokus pada judul "Pementasan Tari Gandrung Sebagai Media Pendidikan Agama Hindu di Pura Dalem Majapahit, Br. Munang-Maning, Desa Pemecutan Kelod, Kota Denpasar". 


\section{Research Methods}

Subagya (2011: 1-2) metode adalah suatu jalan yang akan menghubungkan tentang bagaimana sistem kerja untuk dapat mencapai suatu sasaran yang diperlukan bagi penggunanya. Sehingga untuk mampu memahami suatu obyek sasaran yang nantinya akan dikendaki dalam upaya mencapai sasaran/ tujuan dari pemecahan suatu masalah. Menurut Sujarweni (2014 : 3) menyatakan bahwa penelitian merupakan penyelidikan atau suatu usaha yang sistematis,terkendali, teliti,kritis serta empiris, terhadap sebuah fenomena dalam mencari suatu kebenaran dengan menggunakan langkah- langkah tertentu supaya dapat ditemukan jawaban yang ilmiah terhadap suatu masalah. Jadi metode penelitian merupakan cara atau jalan dalam pengumpulan, pengolahan dan penyajian data menggunakan langkah-langkah tertentu yang dapat dilakukan secara seksama kemudian akan dibahas dan memperoleh pemecahan terhadap segala permasalahan. Tujuan untuk menggunakan metode penelitian yakni agar mempermudah untuk memperoleh data-data dalam penyusunan karya ilmiah.

Pada teknik pengumpulan data dalam penelitian ini ialah menggunakan beberapa teknik, yaitu : 1) teknik observasi non partisipasif, ialah peneliti terjun secara murni sebagai peneliti, 2) teknik wawancara yang dipergunakan adalah wawancara tidak berstruktur, 3) teknik pengumpulan data melalui hasil dari studi dokumentasi, yakni mengumpulkan data-data yang terkait dengan penelitian, bersumberdari buku, jurnal, skripsi, tesis dan lainnya. Penelitian ini menggunakan langkah-langkah sebagai berikut : lokasi penelitian, jenis penelitian , sumber data, pengumpulan data, analisis data, teknik penyajian data dan teknik pengecekan keabsahan data.

\section{Results and Discussion}

\subsection{Prosesi Pementasan Tari Gandrung sebagai Media Pendidikan Agama Hindu di Pura Dalem Majapahit, Br. Munang-Maning, Desa Pemecutan Kelod, Kota Denpasar}

Prosesi merupakan suatu kegiatan yang merujuk kepada perarakan yang sedang bergerak kemudian menjalankan peranannya sebagai bagian dalam suatu upacara. Dalam sebuah pementasan tentunya terdapat prosesi untuk menjalankan pementasan tersebut. Menurut Hardaniwati dkk, (2003: 488) kata pementasan berakar dari kata "pentas" yang memiliki arti lantai tempat pertunjukkan kesenian atau panggung, sedangkan kata pementasan berarti memainkan sesuatu dipanggung. Tari Gandrung adalah tarian yang disakralkan dan dipentaskan di Pura Dalem Majapahit dalam rangkaian piodalan pada purnama sasih kenam saat penyineban.

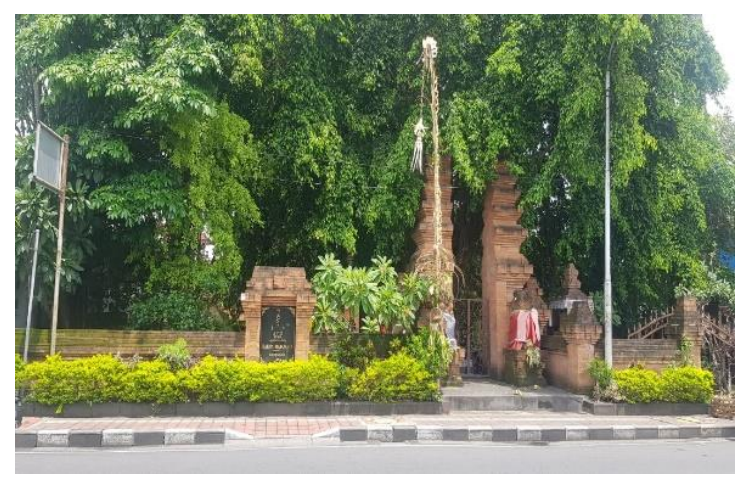

Gambar 1. Pura Dalem Majapahit

Pementasan tari Gandrung di Pura Dalem Majapahit didasari dengan adanya keyakinan masyarakat Desa Pemecutan Kelod khususnya Banjar Munang Maning dengan melaksanakan pementasan tari Gandrung untuk membangkitkan rasa kebersamaan dan semangat untuk melestarikan kebudayaan leluhur. Perjuangan umat beragama untuk mempertahankan seni budaya melalui pementasan tari Gandrung sangat diharapkan agar pemuda-pemudi dari Banjar Munang Maning untuk ikut melestarikan tari Gandrung. Adapun prosesi pementasan tari Gandrung dilaksanakan pada rangkaian piodalan saat nyineb di Pura Dalem Majapahit, Br. Munang-Maning, Desa Pemecutan Kelod, Kota Denpasar, yakni: (1) mengias gelungan gandrung: menggunakan bunga jepun Bali dan bunga gandrung dijadikan sebagai media estetika untuk memberikan keindahan terhadap gelungan yang akan dipergunakan pada saat pementasan berlangsung, (2) memakai make-up: dijadikan sebagai media estetika dalam menampilkan suatu hasil kreatifitas karya menghias wajah saat pementasan, melalui media make-up membuat penari tari Gandrung akan terlihat seperti wanita saat pementasannya, (3) pawintenan penari: dijadikan sebagai media pemberian taksu kepada 
para penari agar dalam menarikan tari Gandrung lebih terpancar aura kesakralannya. Taksu merupakan inner power yang dapat muncul karena adanya keterampilan, kecerdasan, keindahan dan kekuatan spiritual yang dimiliki oleh seorang penari untuk dapat mengekspresikan gerak yang diselaraskan dengan ekspresi iringan, (4) ngaturang bhakti: sebagai media mengaturkan yadnya kepada Ida Sang Hyang Widhi Wasa beserta manifestasinya yang berada diPura Dalem Majapahit, (5) memakai gelungan (6) mecaru (7) mesolah: diawali dengan penari mungka lawang, ngider kalangan, metajeg, ngagem, melelekes, mengibing dan (8) pemuput. Tempat pementasan tari Gandrung di Pura Dalem Majapahit dilaksanakan dalam bentuk kalangan di jaba tengah di Pura Dalem Majapahit, Br. MunangManing, Desa Pemecutan Kelod, Kota Denpasar.

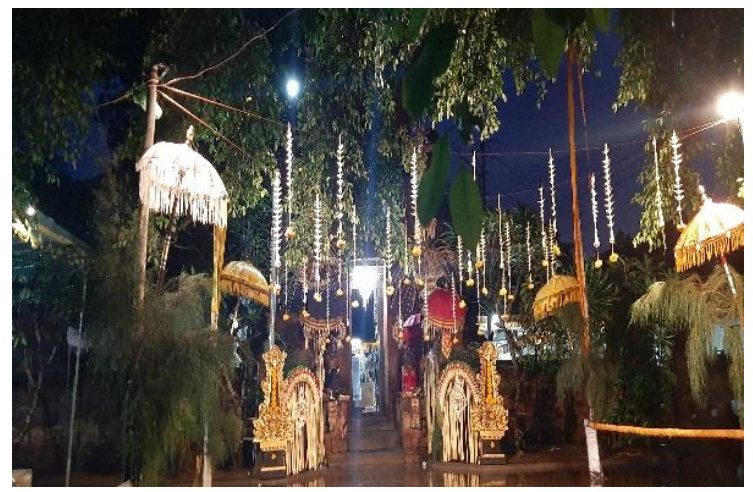

Gambar 2. Tempat pementasan tari Gandrung di Pura Dalem Majapahit

Waktu pementasan tari Gandrung dilaksanakan pada saat nyineb setelah piodalan pada purnama sasih kenam. Sasih kenam jatuh pada bulan Desember. Pemilihan penari Gandrung dipilih oleh Jero Mangku Pura Dalem Majapahit dengan cara mencari atau mengejuk salah satu penonton yang memiliki aura terpancar pada saat pementasan (anak laki-laki berasal dari Banjar Munang Maning yang masih belia sekitaran umur 7-10 tahun) dan mengajaknya untuk melaksanakan ngayah. Serta Jero Mangku Pura Dalem Majapahit akan mendapatkan pawisik dari Ida Bhatara Due Gandrung untuk memilih pragina yang akan menarikan tari Gandrung. Banten yang dipergunakan adalah ngaturang pejati, canang kawas, banten caru dan segehan.

\subsection{Faktor-faktor yang Melatarbelakangi Pementasan Tari Gandrung di Pura Dalem Majapahit, Br. Munang- Maning, Desa Pemecutan Kelod, Kota Denpasar}

Latar belakang merupakan titik tolak dalam memberikan suatu pemahaman kepada para pembaca mengenai apa yang akan disampaikan oleh penulis, serta mampu tersusun dengan jelas. Adapun latar belakang dari pementasan tari Gandrung dilihat dari Fungsi adaptasi, Fungsi pencapaian tujuan, Fungsi integrasi dan Fungsi pemeliharaan pola.

(1) Fungsi adaptasi, sangat berperan penting bagi penari Gandrung dan masyarakat Desa Pemecutan Kelod khususnya Banjar Munang Maning Kota Denpasar. Penari tari Gandrung harus beradaptasi dengan lingkungan yang baru, yang diketahui bahwa penarinya adalah seorang anak lelaki yang harus menarikan tarian Gandrung yang berpenampilan seperti wanita dalam pementasannya.

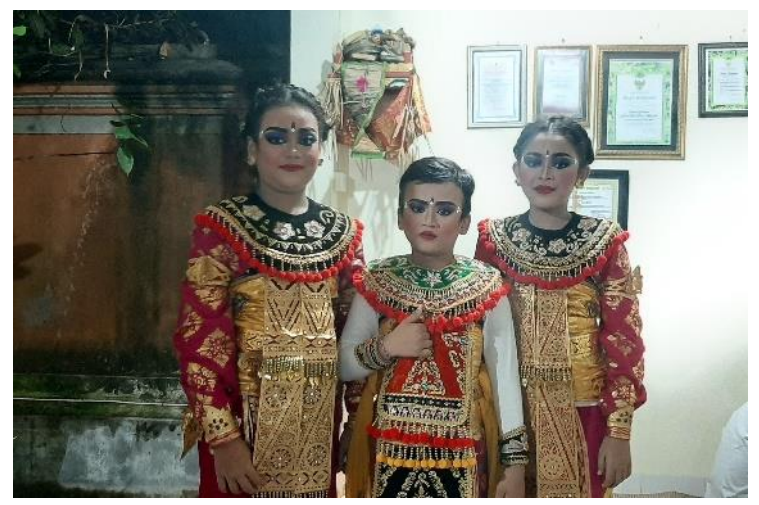

Gambar 3. Penampilan penari tarian Gandrung 
Dengan adanya motivasi dari Jero Mangku Pura Dalem Majapahit dan dukungan dari orang tua penari Gandrung yang juga memberikan pemahaman secara mendalam dengan bahasa yang dimengerti untuk anaknya yang masih memiliki pemikiran anak-anak agar tidak malu dan tidak takut lagi dalam menarikan tari Gandrung. Serta bagi masyarakat Pura Dalem Majapahit Desa Pemecutan Kelod Kota Denpasar, khususnya Banjar Munang Maning dengan adanya pementasan tari Gandrung meyakini bahwa terdapat Sesuunan Due Gandrung yang bersthana di Pura Dalem Majapahit.

(2) Fungsi Pencapaian Tujuan, yakni melestarikan kesenian yang terdapat di Pura Dalem Majapahit yang merupakan tarian sakral yaitu tari Gandrung. Dalam pementasan tari Gandrung dilaksanakan dengan sradha dan bhakti yang tulus dari penari Gandrung dan masyarakat sekitar Banjar Munang Maning. Ngayah merupakan budaya lokal yang telah dilakukan oleh masyarakat Hindu di Pulau Bali sejak jaman dahulu.

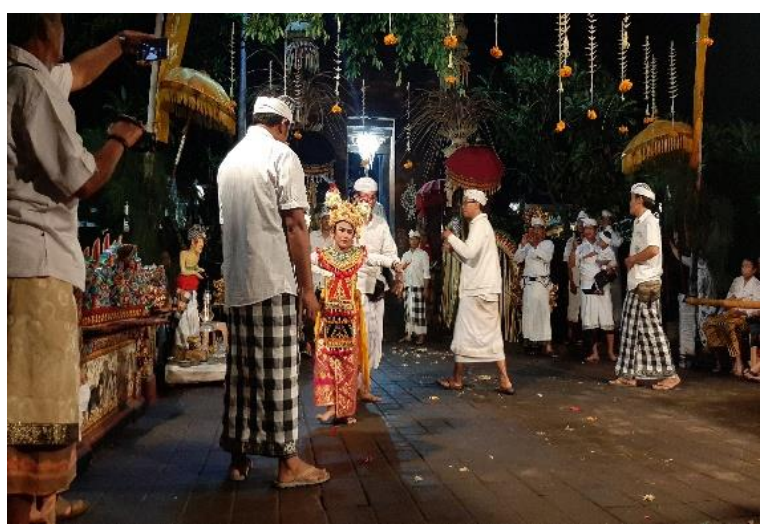

Gambar 4. Pementasan tari Gandrung

Penari yang menarikan tari Gandrung melaksakan ngayah dengan tulus saat pementasan berlangsung. Ngayah merupakan suatu kewajiban sosial bagi masyarakat Hindu di Bali sebagai penerapan ajaran karma marga yang akan dilaksanakan secara gotong royong berdasarkan hati yang tulus ikhlas baik dalam pelaksanaannya di banjar ataupun di Pura (Rai Vivien, 2020). Pelaksanaan pementasan tari Gandrung dijadikan sebagai media mendekati titik keseimbangan integrasi sosial.

(3) Fungsi Integrasi, integrasi merupakan upaya dalam pemeliharaan suatu ikatan kebersamaan, dengan melibatkan elemen tersebut maka dapat mengontrol subsistem dan mencegah adanya gangguan utama. Pementasan tari Gandrung melibatkan seluruh anggota masyarakat Banjar Munang Maning Desa Pemecutan Kelod Kota Denpasar khususnya umat Hindu. Bagi kaum perempuan memiliki peran dalam mempersiapkan berbagai sarana upacara yang berupa banten dan perlengkapan lainnya, sedangkan bagi kaum laki-laki memiliki peran untuk mempersiapkan tempat pelaksanaan upacara-upacara baik berupa, mengias palinggih-palinggih, membuat tetaring, membuat kelakat, mebat, megambel. Kebersamaan yang terdapat dalam pementasan tari Gandrung dilaksanakan oleh sekaa santi, sekaa gong, sekaa igel, tukang banten, masyarakat / penonton lainnya dan para pengibing.

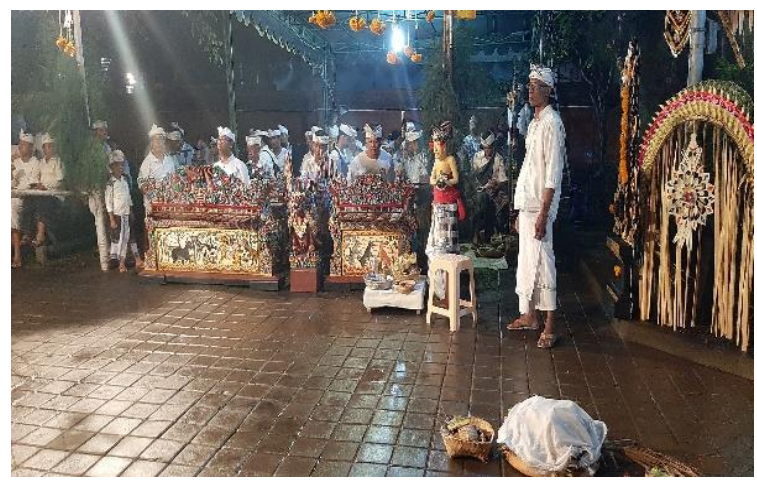

Gambar 4. Pementasan tari Gandrung

Masyarakat Banjar Munang Maning berusaha menjahui konflik. Pelaksanaan pementasan tari Gandrung dijadikan sebagai media mendekati titik keseimbangan integrasi sosial. 
(4) Fungsi Latensi, ialah setiap masyarakat tentunya memiliki pemilihan pola-pola yang harus dipertahankan, dan diperbaiki. Salah satunya masyarakat di Pura Dalem Majapahit Br. Munang-Maning Desa Pemecutan Kelod Kota Denpasar memiliki tarian sakral yakni tari Gandrung yang dimana tarian ini ditarikan oleh penari laki- laki. Dalam pemilihan penari laki-laki di Pura Dalem Majapahit dilaksanakan oleh Jero Mangku melalui pawisik, serta anak lakilaki yang memiliki kelebihan mendapatkan taksu akan terlihat saat pementasan berlangsung. Pada fungsi latensi dijadikan sebagai media untuk membekali individu atau masyarakat dengan aturan dan nilai-nilai dalam bertindak.

\subsection{Nilai Pendidikan Agama Hindu Dalam Pementasan Tari Gandrung Sebagai Media Pendidikan Agama Hindu di Pura Dalem Majapahit Br. Munang-Maning Desa Pemecutan Kelod Kota Denpasar}

Nilai-nilai pendidikan agama Hindu dalam pementasan tari Gandrung yakni : (1) Nilai Keterampilan, dapat dilihat dari keterampilan yang dimiliki oleh setiap orang ada berbagai jenis, seperti keterampilan bidang menari dari penari gandrung, keterampilan megambel dari remaja laki-laki dijadikan media pemersatu antara masyarakat, baik dalam internal penabuh maupun masyarakat luas serta menjadi salah satu upaya dalam pelestarian megambel yang dilakukan oleh para Pembina tabuh di Banjar Munang Maning yakni melatih anak-anak atau remaja laki-laki di Banjar untuk belajar megambel dan, keterampilan membuat banten (majejahitan) yang merupakan contoh kegiatan dari masyarakat untuk menata berbagai bahan sesaji sehingga menjadi keutuhan banten. Majejahitan adalah bagian dari metanding yaitu merangkai sehelai janur dengan berbagai macam bunga dan daun-daunan tertentu. Keterampilan ini dilakukan oleh remaja perempuan dan masyarakat Banjar Munang Maning.

(2) Nilai Etika, merupakan bentuk dari pengendalian diri dalam proses pergaulan hidup bersama dan kehidupan bersama ini seorang manusia harus mengatur dirinya dalam bertingkah laku. Dalam pementasan tari Gandrung dapat terlihat dari bagaimana gerakan tarian yang menunjukkan pakem-pakem tarian sakral dan dalam prosesi pemilihan tari Gandrung di Pura Dalem Majapahit tidaklah sembarangan, hanya masyarakat dari Banjar Munang Maning yang bisa menarikan tari Gandrung khususnya anak laki- laki yang belum mengalami masa akil balik(pubertas). Sesuai dengan konsep Tri Kaya Parisudha, yakni berpikir, berkata dan bertingkah laku yang baik, hal ini dapat direalisasikan dalam pementasan tari Gandrung tersebut, yaitu setiap penari, penabuh, dan jero mangku di Pura Dalem Majapahit, sebelum pementasan dilarang mengkonsumsi daging babi, dan mengalami cuntaka (sebel). Pada saat pementasan berlangsung tidak diijinkan untuk berkata kasar, sebagai salah satu etika dalam berbicara, sebab tari Gandrung merupakan tarian bersifat sakral. Nilai etika juga tercermin pada saat pementasan tari Gandrung terdapat normanorma yang harus dilaksanakan yakni : melaksanakan pawintenan, dan ngaturang bhakti terlebih dahulu bagi yang akan menarikannya, serta waktu pementasannya.

(3) Nilai Estetika yaitu nilai keindahan yang terlihat dari gerak penari yang menarikannya dengan lemah gemulai diawali dengan mungkah lawang, nginder kalangan, metanjeg, ngagem, melelekes, dan mengibing. Tata busananya dari tari Gandrung di Pura Dalem Majapahit mengenakan pakaian tari legong, keunikan dari busana inilah menunjukan bahwa penari laki-laki diperkenankan menggunakan busana penari wanita serta penari Gandrung memakai gelungan Gandrung yang mengandung unsur keindahan dan kesakralan. Busana tari Gandrung terdiri dari : gelungan gandrung, subeng, badong manis, baju putih, gelang kana, tutup dada, lamak, sabuk prada, ampok-ampok, kain prada, selendang, kipas.

(4) Nilai Pelestarian Budaya, yakni kebudayaan merupakan hasil cipta, karsa manusia di dalam memenuhi kebutuhan hidupnya yang begitu kompleks serta mencangkup suatu pengetahuan, seni, keyakinan, hukum adat serta kebiasaan yang telah dilakukan oleh manusia dalam suatu karya yang kemudian menjadikannya suatu ciri khas dari daerah yang latar belakang berbeda. Manusia juga merupakan makhluk yang berbudaya, karena di dalam kehidupan manusia banyak terdapat warisan budaya dari para leluhur agar tetap bisa dijaga dan dilestarikan oleh generasi muda. Dalam menjaga warisan budaya dari leluhur yang terdapat di Pura Dalem Majapahit yaitu tari Gandrung yang merupakan tarian sakral dan ditarikan oleh penari laki-laki. Melalui nilai pelestarian budaya diharapkan agar genari penerus tari Gandrung melaksanakan pementasan tari Gandrung dan tetap mempertahan tradisi yang diwarisikan.

(5) Nilai Cinta Kasih merupakan nilai yang saling mengasihi dan mencintai setulus hati yang dapat memberikan kebaikan, kedamaian dan ketulusan bagi seseorang yang memberikannya. Melalui pementasan tari Gandrung dapat dilihat dari para penonton atau pengibing yang telah menantikan tarian dari penari Gandrung yang akan tampil dalam piodalan di Pura Dalem Majapahit serta penari Gandrung mampu menampilan tampilan yang sangat mempesona dan membuat pengibing merasa senang atau gandrung dan gembira. Serta sebagai penari Gandrung nilai cinta kasih kepada penonton atau pengibing memberikan tampilan yang mempesona dalam kegiatan ngayah di Pura Dalem Majapahit. 


\section{Conclusion}

Simpulan adalah inti dari suatu penelitian yang dapat dengan mudah dipahami isi, maksud dan tujuan penelitian. Berdasarkan hasil analisis dan penyajian data hasil penelitian terkait dengan Pementasan Tari Gandrung Sebagai Media Pendidikan Agama Hindu di Pura Dalem Majapahit Br. Munang-Maning Desa Pemecutan Kelod Kota Denpasar, maka dapat disimpulkan sebagai berikut:

1) Adapun prosesi pementasan tari di Pura Dalem Majapahit Br. Munang-Maning Desa Pemecutan Kelod Kota Denpasar, yakni diawali dari prosesi mengias gelungan Gandrung, pawintenan penari, ngaturang bhakti, ngaturang caru, mesolah dan pemuput. Banten yang dipergunakan adalah ngaturang pejati, canang kawas, banten caru dan segehan dilanjutkan dengan tata rias, tata busana, gerakan, gamelan dan tempat pementasan tari Gandrung.

2) Faktor-faktor yang melatar belakangi pementasan tari Gandrung di Pura Dalem Majapahit Br. Munang-Maning Desa Pemecutan Kelod Kota Denpasar, yakni dapat dilihat dari 1)fungsi adaptasi, 2)fungsi pencapaian tujuan, 3)fungsi integrasi, dan 4)fungsi latensi.

3) Nilai Nilai-nilai Pendidikan Agama Hindu pada Pementasan Tari Gandrung di Pura Dalem Majapahit Br. Munang-Maning Desa Pemecutan Kelod Kota Denpasar, yaitu: 1) Nilai keterampilan, 2) Nilai etika, 3) Nilai estetika, 4) Nilai pelestarian budaya, 5) Nilai cinta kasih.

\section{References}

Beni, S. (2012). Psikologi Pendidikan \& Pengajaran. Yogyakarta: Tim Redaksi CAPS.

Hardaniwati. (2003). Sastra Indonesia dan Daerah Jakarta. Pusat Bahasa.

Ihromi. (2006). Pokok-Pokok Antropologi Budaya. Jakarta: Yayasan Obor.

Ihsan, F. (2011). Dasar-Dasar Kependidikan Komponen MKDK. Jakarta: Rineka Cipta.

Koentjaraningrat. (2004). Manusia dan Kebudayaan di Indonesia. Jakarta: PT Rineka Cipta.

Made Rianta, I. (2020). Konsep Catur Purusartha Dalam Gerak Tari Rejang Sakral Lanang Di Desa Mayong, Buleleng, Bali. Jurnal Seni Pertunjukan, 44.

Nawawati, T. (2013). Etnokoreologi : Pengkajian Tari Etnis \& Kegunaannya Dalam Pendidikan Seni. Proceeding of the International Seminar on Languages and Arts (p. 71). Padang: FBS Universitas Negeri Padang.

Ni Rai Vivien Pitriani. (2020). Tradisi Ngayah Sebagai Wadah Komunikasi Masyarakat Hindu Perspektif Pendidikan Humanis-Religius. Widya Duta, 159.

Subagya, P. (2011). Metode Penelitian Dalam Teori dan Praktek. Jakarta: PT Rineka Cipta.

Sujarweni, W. (2014). Metodologi Penelitian : Lengkap, Praktis dan Mudah Dipahami. Yogyakarta: PT Pustaka Baru.

Yudabhakti, I Made \& Watra, I Wayan. (2007). Filsafat Seni Sakral Dalam Kebudayaan Bali. Surabaya: Paramita. 